\title{
Schisandra chinensis polysaccharides exerts anti-oxidative effect in vitro through Keap1-Nrf2-ARE pathway
}

\author{
Qian $\mathrm{LI}^{1,2,3 *}$ (D), Xiankun QIN ${ }^{1,2}$, Yang YU ${ }^{3}$, Shijian $\mathrm{QUAN}^{3}$, Ping XIAO ${ }^{1,2 *}$
}

\begin{abstract}
Schisandra chinensis polysaccharide (SCP) is extracted from a well-known traditional Chinese medicine Schisandra chinensis (SC). We purified a new compound and would like to analyze the effect of SCP on oxidative stress (OS) in vitro. SCP was identified by high performance liquid chromatography (HPLC) and infrared spectrum (IR). The effect of SCP on cell proliferation, activity of oxidative and anti-oxidative index superoxide dismutase (SOD), catalase (CAT), malonaldehyde (MDA), glutathione (GSH), protein expression of nuclear factor E2-related factor 2 (Nrf2) and its down-stream factors expression, stability of Nrf2, and binding activity of Nrf2 with DNA were tested using different methods in 293T cells. The result showed that SCP enhanced the cell proliferation of $293 \mathrm{~T}$ cells, the contents of GSH and CAT, and the activity of SOD, while decreased the content of MDA. In addition, SCP promoted the transfer of Nrf2 from cytoplasm to nucleus, the binding activity of Nrf2 with DNA, the stability of Nrf2 protein, and prolonged the half-life of Nrf2. SCP showed a strong anti-oxidative activity and activation of the Nrf2 pathway, indicating that SCP had the potential to be developed into the natural anti-oxidant in the future.
\end{abstract}

Keywords: Schisandra chinensis polysaccharide; anti-oxidant; cell proliferation; Nrf2.

Practical Application: SCP processes a strong anti-oxidative activity, which has the potential to be developed into the natural anti-oxidant in the future.

\section{Introduction}

Oxidative stress $(\mathrm{OS})$ refers to the imbalance between oxidation and anti-oxidation, production of a large number of oxidation intermediates (Sies, 2015). OS is always considered to be an important factor leading to aging and disease (Kattoor et al., 2017; Bisht et al., 2017). Many studies have reported that more than $90 \%$ of human diseases are caused by OS (Klieser et al., 2019). OS are usually divided into two categories: endogenous factors and exogenous factors. The endogenous factors mainly include chronic or acute diseases, such as tumors, essential diseases, diabetic nephropathy, trauma, stroke, etc. OS may be caused by several factors (pollution, smoke, diet, etc.), and is therefore involved in various pathologies such as cancer, Alzheimer, etc (Jabarpour et al., 2019; Huang et al., 2019; Yuan et al., 2019).

Polysaccharide, extracted from traditional Chinese medicine, is a kind of carbohydrate (El-Naggar, 2020). At present, numerous studies have shown that most of the polysaccharides have the function of anti-oxidative stress, because they can clear away the excessive free radicals in the body, and inhibit the production of lipid peroxidation. They also can increase the content or activity of many endogenous antioxidant enzymes, so as to repair the imbalance of the anti-oxidation system and the oxidation system, to reduce the imbalance damage caused by oxidative stress (Tang et al., 2019; Khan et al., 2019).

Schisandra chinensis (Turcz.) Baill is the dried mature fruit of Schisandra sphenanthera Rehd. et Wils, which mainly plays the role in protecting the liver, reducing blood sugar and tonifying kidney deficiency of the body (Panossian \& Wikman, 2008). Schisandra polysaccharide (SCP) is the main bioactive components of Schisandra (Rybnikar et al., 2019; Zhang et al., 2018). Previous studies proved that SCP has the effects of anti-oxidation, anti-aging, anti-tumor and anti-mutation, which are all related to its anti-oxidation effects. Some studies have shown that SCP can inhibit the production of free radicals, improve the level of superoxide dismutase (SOD), catalase (CAT) and glutathione (GSH) in mice, reduce the content of malonaldehyde (MDA), and resist lipid peroxidation (Li et al., 2018.; Nowak et al., 2019). Although these studies have found that SCP has significant anti-oxidation ability, the effect and mechanisms of its anti-oxidation stress remain unknown.

The Kelch-like ECH associated protein 1-nuclear factor erythroid 2-related factor 2- antioxidant response element (Keap1-Nrf2-ARE) signaling pathway is closely related to the anti-oxidative effect of the body (Lu et al., 2016; Silva et al., 2018). Nrf2 is an important anti-oxidant stress transcription factor, which mainly exists in the nucleus. It can control a series of antioxidant enzymes or the genes coding of anti-apoptosis protein in the body. Most importantly, Nrf2 can be closely combined with its downstream factor ARE (anti-oxidant response element) on the Nrf2-ARE signaling pathway, leading to the promotion of the expression of many kinds of cyto-protective proteins (Tu et al.,

Received 07 June, 2021

Accepted 22 June, 2021

${ }^{1}$ Liuzhou Maternity and Child Healthcare Hospital, Liuzhou, Guangxi, China

${ }^{2}$ Affiliated Maternity Hospital and Affiliated Children's Hospital of Guangxi University of Science and Technology, Liuzhou, Guangxi, China

${ }^{3}$ Guangzhou University of Chinese Medicine, Guangzhou, Guangdong, China

*Corresponding author: 13978064521@163.com, xiaoping0718@163.com 
2019). At the same time, Nrf2 can promote the downstream phase II detoxification enzyme expression, accelerate the metabolism of toxic substances in the body (Ahmed et al., 2017). Thus, Nrf2/ARE plays an important role in anti-oxidative stress (Petrillo et al., 2020; Ungvari et al., 2019; Barančík et al., 2016).

In the present study, we aimed to explore the effects and mechanism of SCP in OS in 293T cells.

\section{Materials and methods}

\subsection{Materials and reagents}

The dried fruits of Schisandra chinensis were purchased from Guangzhou Baozhilin Pharmacy (China), which were identified as Schisandrae Sinensis Bail by Danyan Zhang, a teacher from the Traditional Chinese Medicine Identification Laboratory of Traditional Chinese Medicine College, Guangzhou University of Chinese Medicine. SCP was isolated by our laboratory. Human embryonic kidney 293T cells were purchased from Cell resource center of Shanghai Academy of Biological Sciences, Chinese Academy of Sciences (Shanghai, China). Dulbecco's Modified Eagle's medium (DMEM) for cell culture and fetal bovine serum (FBS) were purchased from Gibco (Grand Island, NY, USA). GSH, CAT, MDA and SOD commercial kits were ordered from Nanjing Jiancheng Bioengineering Research Institute (Nanjing, China). BCA kit was obtained from Beyotime Biotechnology Co., Ltd (China). NQO1-ARE luciferase report gene was purchased from Guangzhou Funeng Biotechnology Co., Ltd., China. Double luciferase detection kit was from Promega, China. Lipo2000 was purchased from Life science, China. Cycloheximide (CHX) was obtained from Sigma-Aldrich Inc., St Louis, MO, USA. CEB-A, CEB-B and NEB were purchased from Viagene Biotech (Changzhou, China). Nrf2 shRNAs were obtained from Shanghai Jikaigene co., LTD (Shanghai, China). The antibody of Nrf2, NQO1 and HO-1 were purchased from Cell Signaling Technology (Danvers, MA, USA). Dialysis bags were purchased in Guangzhou Fibo Biotechnology Co., Ltd (China). DEAE-52 cellulose was purchased from Whatman (Maidstone, Kent, UK), Sephadex G-100 was obtained from GE (USA).

\subsection{Preparation of SCP}

The SCP was isolated from the dried fruit of Schisandra chinensis. The isolation and purification of SCP need 6 steps: degreasing, extraction, decolorization, deproteinization, separation and purification. The detailed isolation and purification method was shown in Figure S1. The purified SCP samples were freeze dried into powder and stored at $-80^{\circ} \mathrm{C}$ for further use.

\subsection{Identification of SCP by High Performance Liquid Chromatography (HPLC) and Infrared Spectrum (IR)}

The purity and identification of SCP was analyzed by HPLC and IR. Briefly, the purified SCP samples were dissolved in sterilized ultrapure water to the final concentration of $2.5 \mathrm{mg} / \mathrm{mL}$ for HPLC analysis. The HPLC system of Waters 1525 Alliance with Waters 2414 differential detector and Waters 717 plus automatic sampler was applied to the purity analysis of SCP.
The tandem column of Ultra hydrogel $1000(7.8 \times 300 \mathrm{~mm})$ and Ultra hydrogel $500(7.8 \times 300 \mathrm{~mm})$ with a column temperature of $35{ }^{\circ} \mathrm{C}$ were applied. The mobile phase was $0.02 \mathrm{~mol} / \mathrm{L}$ of $\mathrm{KH}_{2} \mathrm{PO}_{4}$ buffer solution with isometric elution processes. The flow rate was $0.8 \mathrm{~mL} / \mathrm{min}$.

The IR spectrum process was as follows: a small amount of SCP powder was taken, mixed it thoroughly with $100 \mathrm{mg}$ of dry $\mathrm{KBr}$ powder, ground it in the mortar of agate in clockwise direction until it was fully uniform, and then a tablet press was used to compress the powder into thin sheets for IR machine analysis (Nexus 670 intelligent Fourier infrared spectrometer, Negoli Corporation, USA).

\subsection{Cell viability detection}

The logarithmic growth 293T cells were digested with $0.25 \%$ trypsin enzyme to single cells, and the cell concentration was counted and calculated. 293T cells were seeded on 96-well plates with the concentration of $3.0 \times 10^{3}$ cells/well, and incubated at $37^{\circ} \mathrm{C}, 5 \% \mathrm{CO}_{2}$ for $12 \mathrm{~h}$. Then SCP drugs were added in cells with the gradient concentrations of $0.1,0.25,0.5,1,1.5,2 \mathrm{mg} / \mathrm{mL}$, and continually incubated for 24,48 and $72 \mathrm{~h}$, respectively. After drug incubation, $10 \mu \mathrm{L} /$ well Methylthiazolyldiphenyl-tetrazolium bromide (MTT) was added according to the manufactory protocol for $2-4 \mathrm{~h}$ incubation at $37{ }^{\circ} \mathrm{C}$ in $5 \% \mathrm{CO}_{2}$ incubator, then the cell supernatant was discarded, $100 \mu \mathrm{L} /$ well dimethyl sulfoxide (DMSO) was added, and shocked thoroughly. Then the absorption values were detected at $570 \mathrm{~nm}$.

\subsection{Detection of GSH, CAT, SOD and MDA assay in 2937 cells}

The logarithmic growth $293 \mathrm{~T}$ cells were seeded to 24 -well plates, and treated with $0.1,0.5$ and $1 \mathrm{mg} / \mathrm{mL}$ of SCP respectively for $24 \mathrm{~h}$ after the cells attached. Tert-butylhydroquinone (tBHQ, $20 \mu \mathrm{M})$ was used as the positive control. Then the cells were collected, the cell proteins were lysated with Radio-Immunoprecipitation Assay (RIPA) lysis buffer, and the protein concentrations were measured with Bicinchoninic Acid (BCA) Protein Assay kits. The levels of GSH, CAT, SOD and MDA were detected according to the manufactory protocol. GSH and CAT were detected at $405 \mathrm{~nm}$ with the unit of $\mu \mathrm{mol} / \mathrm{gprot}$ and $\mathrm{U} / \mathrm{mgprot}$. SOD was detected at $450 \mathrm{~nm}$ with the calculation of inhibitory ratio. MDA was detected at $532 \mathrm{~nm}$ with the unit of $\mathrm{nmol} / \mathrm{mgprot}$.

\subsection{Establishment of Nrf2 shRNA knockdown 293T cells}

The logarithmic growth $293 \mathrm{~T}$ cells were seeded into 24 -well plates with $1.0 \times 10^{5} /$ well. After $24 \mathrm{~h}$, the medium was changed to the fresh medium containing with $6 \mu \mathrm{g} / \mathrm{mL}$ polybrene ), and proper Nrf2 shRNA virus solution (obtained from Shanghai Jikaigene co., LTD, China; virus detail information shown in Figure S1) was added in experimental groups, while the same volume of solution without virus was added in the control group. After cells were incubated at $37^{\circ} \mathrm{C}$ for $4 \mathrm{~h}, 2 \mathrm{~mL}$ fresh medium was added in cells for $24 \mathrm{~h}$ further incubation. Then medium was changed into fresh normal medium, and cells were continually cultured for $24 \mathrm{~h}$ for drug treatment. 


\subsection{The protein expression of Nrf2, NQO1 and HO-1 in WT and Nrf2 shRNA knockdown 293 T cells}

The protein expression of Nrf2, NQO1 and HO-1 in WT and Nrf2 shRNA knockdown 293T cells was detected by Western blot. The drugs of $20 \mu \mathrm{M}$ tBHQ (a classical agonist of Nrf2, positive control) and $0.5,1 \mathrm{mg} / \mathrm{mL}$ of SCP were treated for $24 \mathrm{~h}$ in WT and Nrf2 shRNA knockdown $293 \mathrm{~T}$ cells respectively. Then the protein lysate was collected and the protein concentrations were measured using with BCA Protein Assay kits. A total of $30 \mu \mathrm{g}$ of total protein was taken to load per gel lane for Western blot analysis. The first antibody of Nrf2, NQO1 and HO-1 were used as 1:1000 dilution.

\subsection{NQO1-ARE activation in 293T cells}

The logarithmic growth $293 \mathrm{~T}$ cells were seeded into black 96-well plates with $2.0 \times 10^{3}$ cells/well. After $12 \mathrm{~h}$ of cell seeding, $293 \mathrm{~T}$ cells were then transferred with the double luciferase NQO1-ARE plasmid by Lipo ${ }^{2000}$ transfer kit according to the transfer reagent protocol. After transfection for $6 \mathrm{~h}, 0.1,0.5$, $1 \mathrm{mg} / \mathrm{mL}$ of SCP, and $10 \mu \mathrm{M}$ tBHQ were added into cells, respectively. Then $24 \mathrm{~h}$ later, the luciferase detection reagent was added according to the kit protocol, and the values of each drug treatment were calculated.

\subsection{The protein expression of Nrf2, Keap1 in cytoplasm and Nrf2 in nuclear of $293 \mathrm{~T}$ cells treated by SCP}

293T cells were treated with SCP at concentration of 0.1 , 0.5 , and $1 \mathrm{mg} / \mathrm{mL}$ for 24 , respectively. Then the cell lysate was collected and the cytoplasm and nuclear protein was isolated for detection of Nrf2 and Keap1 protein expression. The cytoplasm and nuclear protein lysis was isolated as follows: after $24 \mathrm{~h}$ treatment of SCP, the cells were washed with pre-chilled Phosphate Buffered Saline (PBS) for 3 times, then $1 \mathrm{~mL}$ PBS was added to per well and the cells were scraped with cell scraper. The cell supernatant was transferred to $1.5 \mathrm{~mL}$ EP tube, and centrifuged at $3000 \mathrm{rpm}$ for $5 \mathrm{~min}$. After the supernatant was discarded, $300 \mu \mathrm{L}$ cytosol extraction buffer A (CEB-A) was added in tube which was put on ice for $10 \mathrm{~min}$, and under a vortex for $30 \mathrm{sec} / 3 \mathrm{~min}$. Then $30 \mu \mathrm{L}$ cytosol extraction buffer B (CEB-B) was added and mixed thoroughly. The mixture was put on ice for $1 \mathrm{~min}$, and centrifuged at $1000 \mathrm{~g}$ for $5 \mathrm{~min}$, and the supernatant (the total cytoplasm protein) was collected. Then $100 \mu \mathrm{L}$ CEB-A was added to the precipitate, mixed thoroughly and centrifuged at $1000 \mathrm{~g}$ for $5 \mathrm{~min}$. The supernatant was discarded, and $40 \mu \mathrm{L}$ nuclear extraction buffer (NEB) was added. The mixture was put under vortex movement for $10 \mathrm{sec}$ to mix thoroughly, placed on ice for $30 \mathrm{~min}$, and put to a vortex $10 \mathrm{sec} / 5 \mathrm{~min}$. Finally the mixture was centrifuged at $1000 \mathrm{~g}$ for $5 \mathrm{~min}$, and the supernatant was collected. The protein concentration in cytoplasm and nuclear was detected by BCA kits. A total of $30 \mu \mathrm{g}$ of total cytoplasm or total nuclear protein was loaded to per gel lane for Western blot analysis, respectively. The first antibody of Nrf2 and Keap1 with 1:1000 dilution were used in this study.

\subsection{The effect of SCP on half-life and stability of Nrf2}

$293 \mathrm{~T}$ cells were treated with the protein synthesis inhibitor cycloheximide $(\mathrm{CHX})$ at the indicated times $(0,10,20$ and
$60 \mathrm{~min}$ ) for $2 \mathrm{~h}$, with or without pretreatment of SCP $(1 \mathrm{mg} / \mathrm{mL})$. The total proteins were collected at the indicated times and the Nrf2 protein expression was analyzed by Western blot method.

\subsection{The effect of SCP on Nrf2-DNA binding activity}

$293 \mathrm{~T}$ cells were treated with SCP $(1 \mathrm{mg} / \mathrm{mL})$ for $12 \mathrm{~h}$, then the cells were harvested for nuclear protein extracts according to the "section 2.6". Cell protein nuclear extracts were subjected into electrophoretic mobility shift assay (EMSA) with a biotinylated human Nrf2 probe followed by the manufacture protocol. Competition experiment was performed in the presence of 25, 80 -fold molar excess of unlabeled probe. Super shift analysis was carried out by adding an anti-Nrf2 antibody to the incubation mixture for $1 \mathrm{~h}$ at $4{ }^{\circ} \mathrm{C}$ prior to electrophoresis. The labeled probe and the unlabeled competitive probe sequences were synthesized by Viagene Biotech Inc (Tampa, FL, USA), and shown as follows: Biotin: 5'-TGGGGAACCTGTGCTGAGTCACTGGAG-3'. Cold: 5'-TGGGGMCCTGTGCTGAGTCACTGGAG-3'. Mutant: 5'-TGGGGAACCTGTGCTGTCACTGGAG-3'.

\subsection{Statistical analysis}

The statistical data in the study were represented as mean \pm standard deviation (SD), and analyzed by One-way ANOVA test with Dunett's t-test of Graphad Prism 5.0 statistical software (GraphPad Software, San Diego, USA). $p<0.05$ and $p<0.01$ were regarded as statistically significant.

\section{Results}

\subsection{The purity and identification analysis of SCP by HPLC and IR}

The HPLC analysis spectrum showed a single high purity peak at the elution time of $32 \mathrm{~min}$ in the established HPLC analysis process (Figure 1A). Figure 1B showed the identification of the SCP by IR spectrum, there showed many special signals for SCP. The absorbed wave numbers were as follows $\left(\mathrm{cm}^{-1}\right)$ : 3416 (Stretching vibration for -OH, N-H), 2929 (Stretching vibration for $-\mathrm{CH}_{2}-$ ), 1609 (Angular vibration for $\mathrm{N}-\mathrm{H}$ ), 1406 (Angular vibration for C-H), 1152 and 1026 (Stretching vibration for C-O-C, special signal for pyranose ring), 773 (Stretching vibration for pyranose ring).

\subsection{Effects of SCP on cell viability of $293 T$ cells}

To evaluate the effects of SCP on the cell viability of $293 \mathrm{~T}$ cells, 293T cells were treated with SCP at concentrations of $0,0.1,0.25,0.5,1,1.5$ and $2 \mathrm{mg} / \mathrm{mL}$ for 24,48 and $72 \mathrm{~h}$, cell optical density was observed. As shown in Figure 2A, it was found that cell viability of 293T was significantly increased with the increase of the concentrations of SCP at 24, 48 and $72 \mathrm{~h}$ $(p<0.05)$. At different time points, compared to the control, SCP at concentrations of $0.1,0.25$ showed no influence in cell viability of 293T cells ( $p>0.05)$, but SCP at concentrations of $0.5,1,1.5$ and $2 \mathrm{mg} / \mathrm{mL}$ promoted it significantly $(p<0.05$; Figure $2 \mathrm{~B}$ ). It was indicated that SCP had no any toxicity for this experiment objector $293 \mathrm{~T}$ cells. 
(A)

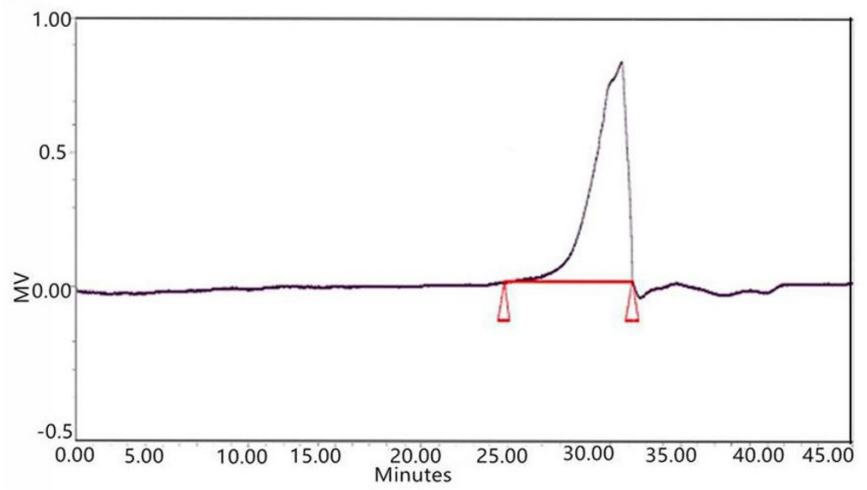

(B)



Figure 1. Identification of SCP. (A) SCP was identified using High Performance Liquid Chromatography (HPLC); (B) SCP was identified by Infrared spectrum. MV stands for millivolts.
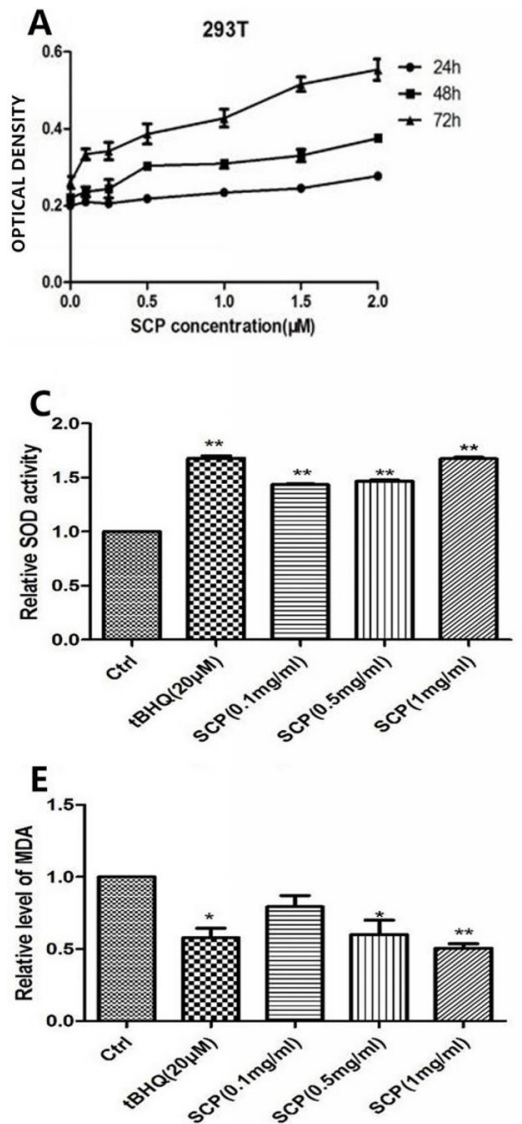

\subsection{Effects of SCP on anti-oxidative effects in $293 T$ cells}

To determine the anti-oxidative effects of SCP, changes of anti-oxidative markers GSH, CAT, SOD and MDA were evaluated in $293 \mathrm{~T}$ cells treated with $20 \mu \mathrm{M}$ tBHQ, and 0 , $0.1,0.5$ and $1 \mathrm{mg} / \mathrm{mL}$ SCP. The results in Figure 2 showed that $\mathrm{tBHQ}$ (the positive control) significantly increased the activity of SOD $(p<0.01$; Figure $2 \mathrm{C}$, ), and the contents of GSH $(p<0.01$; Figure 2D) and CAT $(p<0.01$; Figure $2 \mathrm{~F})$, while markedly reduced the contents of MDA $(p<0.05$; Figure $2 \mathrm{E})$. After $293 \mathrm{~T}$ cells were stimulated with three dosage of SCP (0.1, $0.5,1 \mathrm{mg} / \mathrm{mL}$ ), the levels of SOD (Figure 2C), CAT (Figure 2D) and GSH (Figure $2 \mathrm{~F}$ ) were all remarkably increased $(p<0.05)$, compared with the SCP-untreated group. However, the contents of the lipid peroxidation products MDA was significantly decreased following SCP stimulation, and the effects of SCP was dose-dependent ( $p<0.05$; Figure $2 \mathrm{E})$. Above results suggested that SCP had anti-oxidative effects in $293 \mathrm{~T}$ cells.

\subsection{Effects of SCP on the Nrf2-ARE signaling pathway in $293 T$ cells}

Next, we further explored whether the effects of SCP on oxidation-stress was related with the Nrf2-ARE signaling pathway through Western blot analysis. As shown in Figure 3A, as the positive control, tBHQ significantly promoted protein expression of Nrf2, NQO1 and HO-1 $(p<0.01)$. It was also suggested that
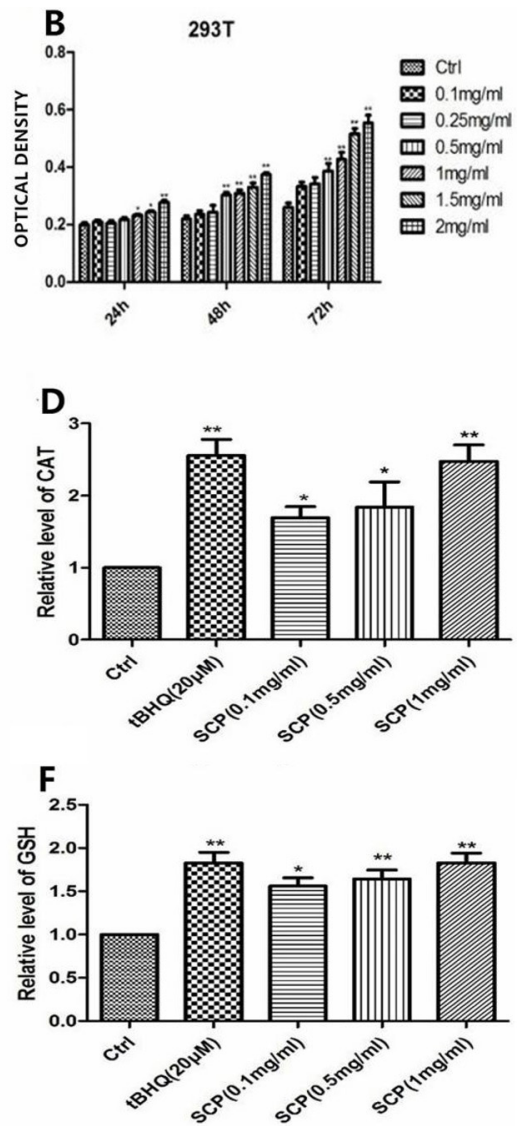

Figure 2. The effect of SCP on cell proliferation and anti-oxidant of 293T cells. (A), (B) After 293T cells were treated with SCP (0, 0.1, 0.25, 0.5, $1,1.5$ and $2 \mathrm{mg} / \mathrm{mL}$ ), cell optical density was evaluated at 24, 48 and $72 \mathrm{~h}$; Relative levels of SOD (C); CAT (D); MDA (E); GSH (F) in 293T cells after treatment with SCP $(0.1,0.5,1 \mathrm{mg} / \mathrm{mL})$ for $24 \mathrm{~h} ;{ }^{*} p<0.05$ and ${ }^{* *} p<0.01$ versus control. Data are presented as the mean \pm SD; $\mathrm{n}=6$. 
A


B
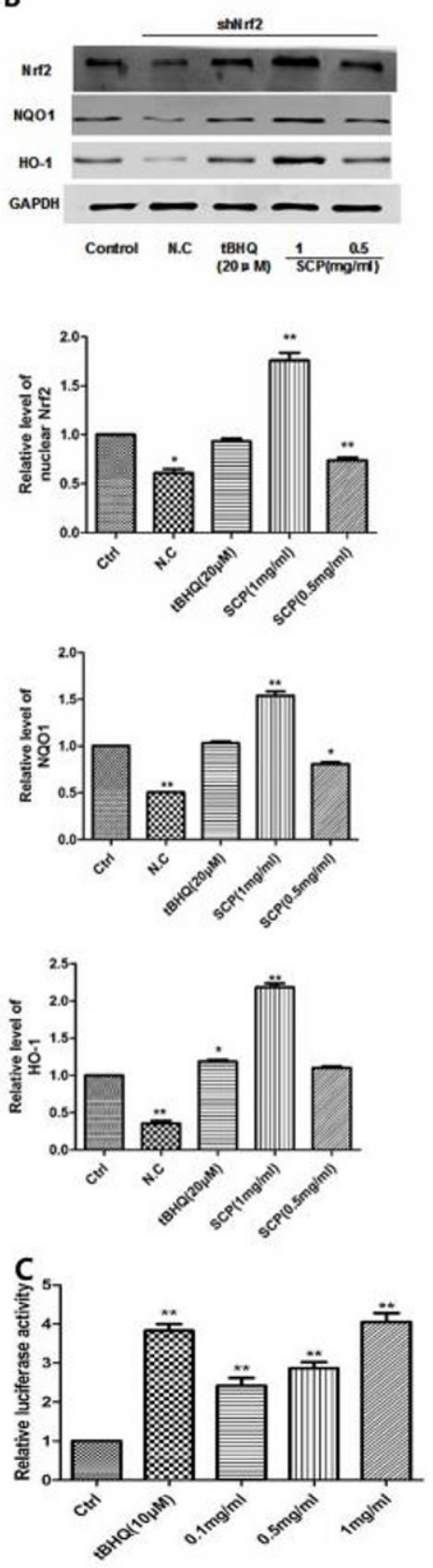

Figure 3. The effect of SCP on the protein expression of Nrf2, NQO1 and HO-1, and NQO1-antioxidant response element-luciferase activity in $293 \mathrm{~T}$ cells. (A) The protein levels of Nrf2, NQO1 and HO-1 in WT 293T cells after treatment with SCP $(0.1,0.5 \mathrm{and} 1 \mathrm{mg} / \mathrm{mL})$ for $24 \mathrm{~h} \mathrm{by}$ Western blot analysis, tBHQ as the positive control group; (B) The protein levels of Nrf2, NQO1 and HO-1 in Nrf2 knockdown 293T cells after treatment with SCP $(0.5$ and $1 \mathrm{mg} / \mathrm{mL})$ for $24 \mathrm{~h}$ by Western blot analysis, tBHQ as the positive control group; (C) 293T cells were transfected with antioxidant response element-luciferase or control plasmids for $6 \mathrm{~h}$ and followed by SCP treatment for $24 \mathrm{~h}$, then NQO1-antioxidant response element-luciferase activity was measured in $293 \mathrm{~T}$ cells; ${ }^{*} p<0.05$ and ${ }^{* *} p<0.01$ relative to control; Data are presented as the mean \pm SD; $\mathrm{n}=3$.

the protein expression of Nrf2, NQO1 and HO-1 in SCP-treated WT $293 \mathrm{~T}$ cells were significantly increased, compared with the SCP-untreated control 293T cells $(p<0.05)$.

Subsequently, in order to identify the above results, we continually tested the protein expression of Nrf2, NQO1 and $\mathrm{HO}-1$ in Nrf2 shRNA knockdown 293T cells (Figure 3B). After the cells were treated with SCP $(0.5$ and $1 \mathrm{mg} / \mathrm{mL})$ for $24 \mathrm{~h}$ in Nrf2 shRNA knockdown 293T cells, the protein expression of Nrf2, NQO1 and
HO-1 were dramatically increased compared with SCP-untreated Nrf2 knockdown 293T cells $(p<0.05)$. It was indicated that SCP activated the Nrf2-ARE signaling pathway in 293T cells.

\subsection{Effect of SCP on NQO1-ARE activation in 293T cells}

Except the knockdown of Nrf2 by shRNA, the double luciferase NQO1-ARE reporter gene was also used to detect the effects of SCP on NQO1-antioxidant response element-luciferase activity in 
$293 \mathrm{~T}$ cells. The results showed that there was a markedly increase in the luciferase activity in the positive control group treated with tBHQ $(p<0.01$; Figure $3 \mathrm{C})$. Furthermore, SCP significantly increased the NQO1-antioxidant response element-luciferase activity in a dose dependent manner $(p<0.01$; Figure $3 \mathrm{C})$. Above results further confirmed that SCP could activate the Nrf2-ARE signaling pathway.

\subsection{Effects of SCP on the protein expression of Nrf2, Keap1 in cytoplasm and Nrf2 in nuclear of 293T cells}

As mentioned in the above results, SCP could activate the Nrf2-ARE signaling pathway. However, how it worked remained unclear. Next, we treated $293 \mathrm{~T}$ cells with SCP at concentrations of $0.1,0.5$ and $1 \mathrm{mg} / \mathrm{mL}$, and continually detected the expression levels of Nrf2 in cytoplasm and nuclear, and the Keap1 levels in cytoplasm by Western blot assay (Figure $4 \mathrm{~A}$ ). The results showed that, compared to the control, SCP $(0.1,0.5$ and $1 \mathrm{mg} / \mathrm{mL})$ inhibited the expression levels of Nrf2 (Figure 4B) and Keap1 (Figure $4 \mathrm{C}$ ) in cytoplasm $(p<0.05)$. Moreover, the nuclear Nrf2 levels were promoted with the increased SCP concentrations (Figure $4 \mathrm{D}, p<0.01$ ). This result exhibited that SCP could promote the dissociation of Keap 1 and Nrf2 in the cytoplasm to activate the Nrf2/ARE pathway.

\subsection{SCP prolonged the half-life of Nrf2 and enhanced the binding activity of Nrf2 and DNA}

At the same time, we tested the effect of SCP on half-life of Nrf2 following treatment with CHX and CHX+SCP (Figure 5A). It was found that SCP could prolong the half-life of Nrf2

(A)



(B)

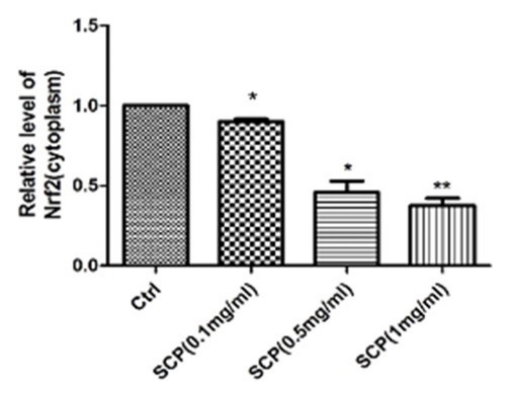

(Figure 5B), indicating the stability of $\mathrm{Nrf} 2$ was induced by SCP in some degree. Finally, we detected the effects of SCP on DNA binding activity of Nrf2 by EMSA experiment (Figure 6). The results showed that SCP could enhance the binding activity of Nrf2 and DNA.

\section{Discussion}

Schisandra chinensis (SC) is a common herbal medicine with sedative and tonic actions (Hancke et al., 1999), whcih can significantly enhance the antioxidant function in animal through inhibiting free radicals formnation or directly scavenging free radicals (Cheng et al., 2013). SCP is extracted from SC with a molecular weight of $5.3 \times 10^{3} \mathrm{Da}$, shows non-toxic and harmless, and possesses health benefits and pharmacological values (Li et al., 2018). Especially, SCP is reported to possess higher anti-oxidative activity and safety as compared with inorganic selenium (Chen \& Ji, 2007). In this experiment, we first investigated the anti-oxidative effects of SCP in 293T cells, and SCP can promote anti-oxidative function of $293 \mathrm{~T}$ cells, and activate the Nrf2 pathway.

As previously reported, the production and increase of reactive oxygen species (ROS) is the beginning of oxidative damage, and also the source and condition of various diseases (Fetoni et al., 2019; Liochev, 2013). Therefore, the key point of disease prevention and treatment is to inhibit and reduce the content and activity of ROS (Van Acker \& Coenye, 2017). GSH with scavenging free radicals, is a kind of low molecular scavenger (Estrela et al., 2016), which can scavenge $\mathrm{O}_{2}, \mathrm{H}_{2} \mathrm{O}_{2}$, $\mathrm{LOOH}$ and so on, making the body produce OS disorder

(C)

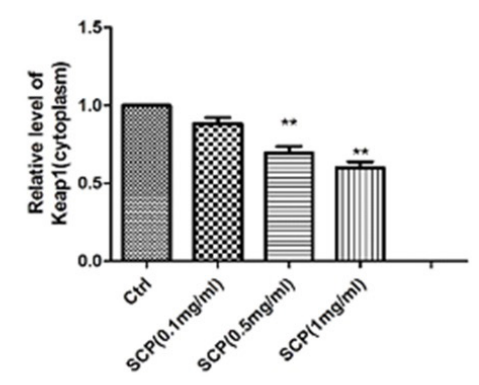

(D)



Figure 4. The effect of SCP on the protein expression of cytoplasm Nrf2, Keap1 and nuclear Nrf2. (A) The protein levels of cytoplasm Nrf2, cytoplasm Keap 1 and nuclear Nrf2 in $293 \mathrm{~T}$ cells were determined by Western blot analysis after treatment with SCP $(0.1,0.5 \mathrm{and} 1 \mathrm{mg} / \mathrm{mL})$ for $24 \mathrm{~h}$, tBHQ as the positive control group; Quantification of cytoplasm Nrf2 (B) cytoplasm Keap1; (C) nuclear Nrf2; (D) expression in 293T cells was taken; ${ }^{*} p<0.05$ and ${ }^{* *} p<0.01$ relative to control; Data are presented as the mean $\pm \mathrm{SD} ; \mathrm{n}=3$. 


\section{(A)}

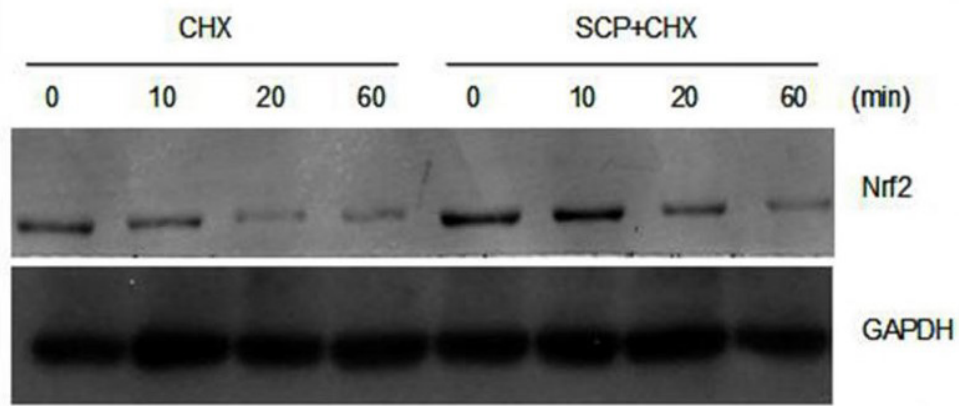

(B)

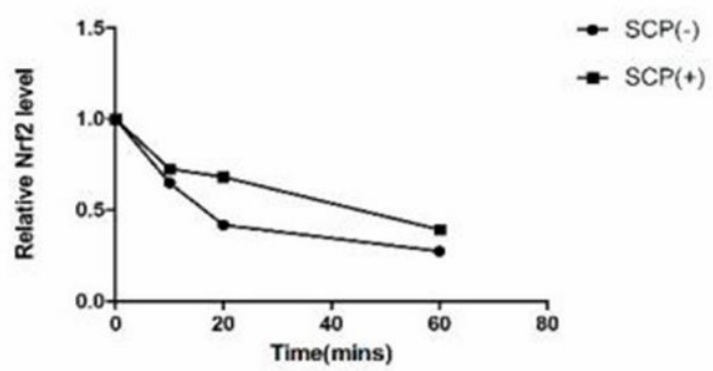

Figure 5. The effect of SCP on the protein stability of Nrf2. (A) The protein expression of Nrf2 was measured using Western blot analysis in 293 cells treated with the protein synthesis inhibitor CHX at the indicated time with or without pretreatment of SCP (1 mg/mL) for $2 \mathrm{~h}$; (B) Quantification of the protein levels relative to control was done; Data are presented as the mean \pm SD; $n=3$. GAPDH stands for Glyceraldehyde3-phosphate dehydrogenase.

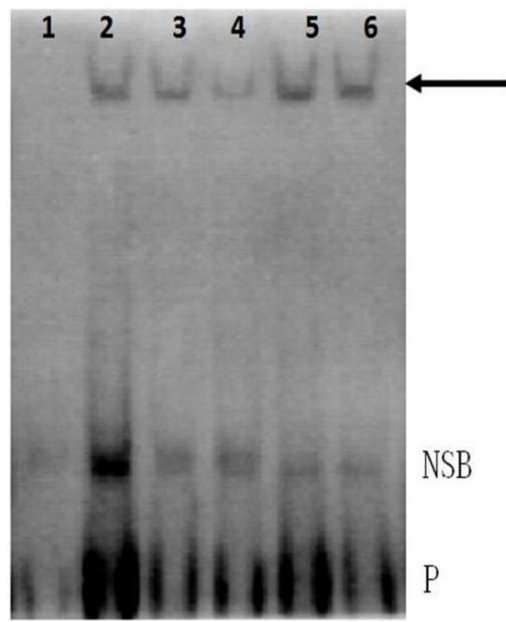

\begin{tabular}{|l|l|l|}
\hline Samples & SCP & Probe \\
\hline 1 & - & bio-NrF2 \\
\hline 2 & $12 \mathrm{~h}$ & bio-NrF2 \\
\hline 3 & $12 \mathrm{~h}$ & $25 \mathrm{X}$ cold-NrF2 \\
\hline 4 & $12 \mathrm{~h}$ & $80 \mathrm{X}$ cold-NrF2 \\
\hline 5 & $12 \mathrm{~h}$ & $25 \mathrm{X}$ Mut-NrF2 \\
\hline 6 & $12 \mathrm{~h}$ & $80 \mathrm{X}$ Mut-NrF2 \\
\hline
\end{tabular}

Arrow: DNA binding proteins

NSB: Non-Specific Binding

P: Free Biotin Labeled Probe

Figure 6. The effect of SCP on Nrf2-DNA binding activity. Enhanced Nrf2 DNA binding activity was determined by EMSA assay in SCP treated $293 \mathrm{~T}$ cells; Competition experiment was performed in the presence of 25,80 -fold molar excess of unlabeled probe.

factors (Du et al., 2020). CAT can rapidly decompose the free hydrogen and oxygen $\left(\mathrm{OH}^{-}\right)$produced by the body, protect the stability of the internal environment of the body, maintain the normal activity of cells, and repair the damage caused by various exogenous or endogenous OS (Glorieux \& Calderon, 2017). Thus, the activity of CAT is one of the important indexes to evaluate the antioxidant capacity of the body (Krych-Madej \& Gebicka, 2017; Kirkman \& Gaetani, 2007). Superoxide dismutase (SOD) is a new enzyme preparation (Lewandowski et al., 2018), which is regarded as the most magical enzyme and the garbage collector of human body in life science and technology (Miao \& St Clair, 2009). SOD is also the natural enemy of oxygen free 
radicals, and the foundation of life and health (Lin et al., 2020). In addition, there are many ways to produce oxygen free radicals, including enzyme system and non enzyme system (Guo et al., 2020). MDA is produced from polyunsaturated fatty acids (PUFAs) both by chemical reactions and by reactions catalyzed by enzymes, and can directly and accurately reflect the degree of lipid peroxidation, and indirectly indicate whether the cells are seriously damaged (Fão et al., 2019). Therefore, the content of MDA is also one of the important indexes to evaluate the antioxidant capacity. In this experiment, the high, middle and low dose groups of SCP can increase the content of GSH, and the activity of CAT and SOD, and reduce the content of MDA in a dose-dependent manner, indicating that SCP has the function of providing anti-oxidative ability in vitro.

The Nrf2/ARE pathway is the most core antioxidant pathway in the body to defence against OS (Raghunath et al., 2018). There are many downstream genes regulated by Nrf2. Once Nrf2 is activated, the body will show a variety of responses (Natsch \& Emter, 2016; Krajka-Kuźniak et al., 2017; Li et al., 2014). In this study, we found that SCP can increase the levels of Nrf2, NQO1 and HO-1 no matter in WT or shRNA knockdown 293T cells. ARE luciferase reporter gene system is recognized as a system to verify whether a pathway is activated (Krajka-Kuźniak et al., 2017). Therefore, in this study, we detected the changes of ARE luciferase reporter gene level in 293T cells after SCP treatment. The result displayed that SCP can activated the luciferase activity in a dose dependent manner. In addition, through detection of half-life and DNA binding activity in SCP-treated 293T cells, we also found that SCP can prolong the half-life of Nrf2, and enhance the stability and the DNA binding activity of Nrf2. $\mathrm{tBHQ}$, as one of the recognized activators of Keapl/Nrf2/ARE pathway, which can activate the Keapl/Nrf2/ARE pathway, and further activate the transcriptional activity of detoxification enzyme and anti-oxidant factor of the downstream of Nrf2, so as to resist the damage caused by OS (Li et al., 2014). SCP shows a protective effect on ethanol-induced liver injury in mice and cells via inhibiting the expression of CYP2E1 protein and then alleviating oxidative stress injury induced by ethanol (Yuan et al., 2018). This study provided the evidence that SCP can activate the Nrf2/ARE pathway, demonstrated by activation of the expression of $\mathrm{Nrf} 2$ and its downstream genes, promotion of the binding activity of Nrf2 to DNA, and the stability of nucleus $\mathrm{Nrf2}$, and prolongation of half-life of Nrf2.In conclusion, this study proved that SCP exerts oxidative effects through increasing the expression of antioxidant enzymes and detoxifying enzymes. Further, SCP can activate the Nrf2/ARE signaling pathway by regulating the expression of $\mathrm{Nrf2}$ and its downstream genes, enhancing the binding activity of Nrf2 and DNA, promoting the stability of nucleus Nrf2, and prolonging the protein half-life of Nrf2. It is indicated that SCP has the function of anti-oxidation and anti-aging, but the deeply molecular mechanism of SCP remains to be further studied.

\section{Ethical approval}

This study is approved by the Ethics Committee of Liuzhou Municipal Maternity and Child Healthcare Hospital.

\section{Availability of data and material}

The datasets used or analyzed during the current study are available from the corresponding author on reasonable request.

\section{Funding}

This study was supported by the Project: Schisandra chinensis regulates endogenous antioxidant gene and transporter via the ERK/p38-nrf2 pathway and the reducing toxicity mechanism of Schisandra chinensis compatibility of cyclosporine A (No.81473582)

\section{Author contributions}

All authors made substantial contributions to conception and design, acquisition of data, or analysis and interpretation of data; took part in drafting the article or revising it critically for important intellectual content; agreed to submit to the current journal; gave final approval of the version to be published; and agree to be accountable for all aspects of the work.

\section{Reference}

Ahmed, S. M., Luo, L., Namani, A., Wang, X. J., \& Tang, X. (2017). Nrf2 signaling pathway: pivotal roles in inflammation. Biochimica et Biophysica Acta, Molecular Basis of Disease, 1863(2), 585-597. http://dx.doi.org/10.1016/j.bbadis.2016.11.005. PMid:27825853.

Barančík, M., Gresova, L., Bartekova, M., \& Dovinova, I. (2016). Nrf2 as a key player of redox regulation in cardiovascular diseases. Physiological Research, 65(Suppl 1), S1-S10. http://dx.doi.org/10.33549/ physiolres.933403. PMid:27643930.

Bisht, S., Faiq, M., Tolahunase, M., \& Dada, R. (2017). Oxidative stress and male infertility. Nature Reviews. Urology, 14(8), 470-485. http:// dx.doi.org/10.1038/nrurol.2017.69. PMid:28508879.

Chen, W. J., \& Ji, Y. B. (2007). Progress on pharmacological action of fructus schisandrae polysaccharide. Food Drug, 9, 66-67.

Cheng, N., Ren, N. Y., Gao, H., Lei, X. S., Zheng, J. B., \& Cao, W. (2013). Antioxidant and hepatoprotective effects of Schisandra chinensis pollen extract on CCl4-induced acute liver damage in mice. Food and Chemical Toxicology, 55, 234-240. http://dx.doi.org/10.1016/j. fct.2012.11.022. PMid:23201450.

Du, Y., Wang, W. L., He, T., Sun, Y. X., Lv, X. T., Wu, Q. Y., \& Hu, H. Y. (2020). Chlorinated effluent organic matter causes higher toxicity than chlorinated natural organic matter by inducing more intracellular reactive oxygen species. The Science of the Total Environment, 701, 134881. http://dx.doi.org/10.1016/j.scitotenv.2019.134881. PMid:31710900.

El-Naggar, M. E., Othman, S. I., Allam, A. A., \& Morsy, O. M. (2020). Synthesis, drying process and medical application of polysaccharidebased aerogels. International Journal of Biological Macromolecules, 145, 1115-1128. http://dx.doi.org/10.1016/j.ijbiomac.2019.10.037. PMid:31678101.

Estrela, J. M., Ortega, A., Mena, S., Sirerol, J. A., \& Obrador, E. (2016). Glutathione in metastases: from mechanisms to clinical applications. Critical Reviews in Clinical Laboratory Sciences, 53(4), 253-267. http://dx.doi.org/10.3109/10408363.2015.1136259. PMid:26754151.

Fão, L., Mota, S. I., \& Rego, A. C. (2019). Shaping the Nrf2-ARE-related pathways in Alzheimer's and Parkinson's diseases. Ageing Research Reviews, 54, 100942.http://dx.doi.org/10.1016/j.arr.2019.100942. PMid:31415806.

Fetoni, A. R., Paciello, F., Rolesi, R., Paludetti, G., \& Troiani, D. (2019). Targeting dysregulation of redox homeostasis in noise-induced hearing loss: oxidative stress and ROS signaling. Free Radical 
Biology \& Medicine, 135, 46-59. http://dx.doi.org/10.1016/j. freeradbiomed.2019.02.022. PMid:30802489.

Glorieux, C., \& Calderon, P. B. (2017). Catalase, a remarkable enzyme: targeting the oldest antioxidant enzyme to find a new cancer treatment approach. Biological Chemistry, 398(10), 1095-1108. http://dx.doi. org/10.1515/hsz-2017-0131. PMid:28384098.

Guo, Q., Li, F., Duan, Y., Wen, C., Wang, W., Zhang, L., Huang, R., \& Yin, Y. (2020). Oxidative stress, nutritional antioxidants and beyond. Science China, Life Sciences, 63(6), 866-874. http://dx.doi. org/10.1007/s11427-019-9591-5. PMid:31705360.

Hancke, J. L., Burgos, R. A., \& Ahumada, F. (1999). Schisandra chinensis (Turcz.) Baill. Fitoterapia, 70(5), 451-471. http://dx.doi.org/10.1016/ S0367-326X(99)00102-1.

Huang, P. S., Wang, C. S., Yeh, C. T., \& Lin, K. H. (2019). Roles of thyroid hormone-associated microRNAs affecting oxidative stress in human hepatocellular carcinoma. International Journal of Molecular Sciences, 20(20), 5220. http://dx.doi.org/10.3390/ijms20205220. PMid:31640265.

Jabarpour, M., Rashtchizadeh, N., Argani, H., Ghorbanihaghjo, A., Ranjbarzadhag, M., Sanajou, D., Panah, F., \& Alirezaei, A. (2019). The impact of dyslipidemia and oxidative stress on vasoactive mediators in patients with renal dysfunction. International Urology and Nephrology, 51(12), 2235-2242. http://dx.doi.org/10.1007/ s11255-019-02319-7. PMid:31641998.

Kattoor, A. J., Pothineni, N. V. K., Palagiri, D., \& Mehta, J. L. (2017). Oxidative stress in atherosclerosis. Current Atherosclerosis Reports, 19(11), 42. http://dx.doi.org/10.1007/s11883-017-0678-6. PMid:28921056.

Khan, T., Date, A., Chawda, H., \& Patel, K. (2019). Polysaccharides as potential anticancer agents-a review of their progress. Carbohydrate Polymers, 210, 412-428. http://dx.doi.org/10.1016/j.carbpol.2019.01.064. PMid:30732778.

Kirkman, H. N., \& Gaetani, G. F. (2007). Mammalian catalase: a venerable enzyme with new mysteries. Trends in Biochemical Sciences, 32(1), 44-50. http://dx.doi.org/10.1016/j.tibs.2006.11.003. PMid:17158050.

Klieser, E., Mayr, C., Kiesslich, T., Wissniowski, T., Fazio, P. D., Neureiter, D., \& Ocker, M. (2019). The crosstalk of miRNA and oxidative stress in the liver: from physiology to pathology and clinical implications. International Journal of Molecular Sciences, 20(21), 5266. http:// dx.doi.org/10.3390/ijms20215266. PMid:31652839.

Krajka-Kuźniak, V., Paluszczak, J., \& Baer-Dubowska, W. (2017). The Nrf2-ARE signaling pathway: an update on its regulation and possible role in cancer prevention and treatment. Pharmacological Reports, 69(3), 393-402. http://dx.doi.org/10.1016/j.pharep.2016.12.011.

Krych-Madej, J., \& Gebicka, L. (2017). Interactions of nitrite with catalase: enzyme activity and reaction kinetics studies. Journal of Inorganic Biochemistry, 171, 10-17. http://dx.doi.org/10.1016/j. jinorgbio.2017.02.023. PMid:28282582.

Lewandowski, L., Kepinska, M., \& Milnerowicz, H. (2018). Inhibition of copper-zinc superoxide dismutase activity by selected environmental xenobiotics. Environmental Toxicology and Pharmacology, 58, 105113. http://dx.doi.org/10.1016/j.etap.2017.12.022. PMid:29310006.

Li, S., Li, J., Shen, C., Zhang, X., Sun, S., Cho, M., Sun, C., \& Song, Z. (2014). tert-Butylhydroquinone (tBHQ) protects hepatocytes against lipotoxicity via inducing autophagy independently of Nrf2 activation. Biochimica et Biophysica Acta, 1841(1), 22-33. http:// dx.doi.org/10.1016/j.bbalip.2013.09.004. PMid:24055888.

Li, Z., He, X., Liu, F., Wang, J., \& Feng, J. (2018). A review of polysaccharides from Schisandra chinensis and Schisandra sphenanthera: properties, functions and applications. Carbohydrate Polymers, 184, 178-190. http://dx.doi.org/10.1016/j.carbpol.2017.12.058. PMid:29352909.
Lin, S. P., Tu, C., Huang, W., Wu, Y., Lin, P. Y., Ye, S., Long, Y., Xu, W., Chen, S., Wen, Y. S., Ou, Y., Li, X., \& Chen, X. H. (2020). Acute-phase serum superoxide dismutase level as a predictive biomarker for stroke-associated infection. The International Journal of Neuroscience, 130(2), 186-192. http://dx.doi.org/10.1080/00207454.2019.166779 0. PMid:31696761.

Liochev, S. I. (2013). Reactive oxygen species and the free radical theory of aging. Free Radical Biology \& Medicine, 60, 1-4. http:// dx.doi.org/10.1016/j.freeradbiomed.2013.02.011. PMid:23434764.

Lu, M. C., Ji, J. A., Jiang, Z. Y., \& You, Q. D. (2016). The keap1-Nrf2ARE pathway as a potential preventive and therapeutic target: an update. Medicinal Research Reviews, 36(5), 924-963. http://dx.doi. org/10.1002/med.21396. PMid:27192495.

Miao, L., \& St Clair, D. K. (2009). Regulation of superoxide dismutase genes: implications in disease. Free Radical Biology \& Medicine, 47(4), 344-356. http://dx.doi.org/10.1016/j.freeradbiomed.2009.05.018. PMid:19477268.

Natsch, A., \& Emter, R. (2016). Nrf2 activation as a key event triggered by skin sensitisers: the development of the stable KeratinoSens reporter gene assay. Alternatives to Laboratory Animals, 44(5), 443-451. http://dx.doi.org/10.1177/026119291604400513. PMid:27805827.

Nowak, A., Zaklos-Szyda, M., Blasiak, J., Nowak, A., Zhang, Z., \& Zhang, B. (2019). Potential of Schisandra chinensis (Turcz.) Baill. in human health and nutrition: a review of current knowledge and therapeutic perspectives. Nutrients, 11(2), 333. http://dx.doi. org/10.3390/nu11020333. PMid:30720717.

Panossian, A., \& Wikman, G. (2008). Pharmacology of Schisandra chinensis Bail.: an overview of Russian research and uses in medicine. Journal of Ethnopharmacology, 118(2), 183-212. http://dx.doi. org/10.1016/j.jep.2008.04.020. PMid:18515024.

Petrillo, S., Schirinzi, T., Di Lazzaro, G., D’Amico, J., Colona, V. L., Bertini, E., Pierantozzi, M., Mari, L., Mercuri, N. B., Piemonte, F., \& Pisani, A. (2020). Systemic activation of Nrf2 pathway in Parkinson's disease. Movement Disorders, 35(1), 180-184. http:// dx.doi.org/10.1002/mds.27878. PMid:31682033.

Raghunath, A., Sundarraj, K., Nagarajan, R., Arfuso, F., Bian, J., Kumar A. P., Sethi, G., \& Perumal, E. (2018). Antioxidant response elements: discovery, classes, regulation and potential applications. Redox Biology, 17, 297-314. http://dx.doi.org/10.1016/j.redox.2018.05.002. PMid:29775961.

Rybnikar, M., Smejkal, K., \& Zemlicka, M. (2019). Schisandra chinensis and its phytotherapeutical applications. Ceska a Slovenska Farmacie, 68(3), 95-118. PMid:31431019.

Sies, H. (2015). Oxidative stress: a concept in redox biology and medicine. Redox Biology, 4, 180-183. http://dx.doi.org/10.1016/j. redox.2015.01.002. PMid:25588755.

Silva, M. F., Pruccoli, L., Morroni, F., Sita, G., Seghetti, F., Viegas, C., \& Tarozzi, A. (2018). The Keap1/Nrf2-ARE pathway as a pharmacological target for chalcones. Molecules, 23(7), 1803. http://dx.doi.org/10.3390/ molecules23071803. PMid:30037040.

Tang, C., Ding, R., Sun, J., Liu, J., Kan, J., \& Jin, C. (2019). The impacts of natural polysaccharides on intestinal microbiota and immune responses - a review. Food \& Function, 10(5), 2290-2312. http:// dx.doi.org/10.1039/C8FO01946K. PMid:31032827.

Tu, W., Wang, H., Li, S., Liu, Q., \& Sha, H. (2019). The anti-inflammatory and anti-oxidant mechanisms of the keap1/Nrf2/ARE signaling pathway in chronic diseases. Aging and Disease, 10(3), 637-651. http://dx.doi.org/10.14336/AD.2018.0513. PMid:31165007.

Ungvari, Z., Tarantini, S., Nyul-Toth, A., Kiss, T., Yabluchanskiy, A., Csipo, T., Balasubramanian, P., Lipecz, A., Benyo, Z., \& Csiszar, A. (2019). Nrf2 dysfunction and impaired cellular resilience to oxidative 
stressors in the aged vasculature: from increased cellular senescence to the pathogenesis of age-related vascular diseases. GeroScience, 41(6), 727-738. http://dx.doi.org/10.1007/s11357-019-00107-w. PMid:31655958.

Van Acker, H., \& Coenye, T. (2017). The role of reactive oxygen species in antibiotic-mediated killing of bacteria. Trends in Microbiology, 25(6), 456-466. http://dx.doi.org/10.1016/j.tim.2016.12.008. PMid:28089288.

Yuan, R., Tao, X., Liang, S., Pan, Y., He, L., Sun, J., Wenbo, J., Li, X., Chen, J., \& Wang, C. (2018). Protective effect of acidic polysaccharide from Schisandra chinensis on acute ethanol-induced liver injury through reducing CYP2E1-dependent oxidative stress. Biomedicine and Pharmacotherapy, 99, 537-542. http://dx.doi.org/10.1016/j. biopha.2018.01.079. PMid:29902864.

Yuan, T., Yang, T., Chen, H., Fu, D., Hu, Y., Wang, J., Yuan, Q., Yu, H., Xu, W., \& Xie, X. (2019). New insights into oxidative stress and inflammation during diabetes mellitus-accelerated atherosclerosis. Redox Biology, 20, 247-260. http://dx.doi.org/10.1016/j.redox.2018.09.025. PMid:30384259.

Zhang, M., Xu, L., \& Yang, H. (2018). Schisandra chinensis fructus and its active ingredients as promising resources for the treatment of neurological diseases. International Journal of Molecular Sciences, 19(7), 1970. http://dx.doi.org/10.3390/ijms19071970. PMid:29986408. 


\section{Supplementary Material}

Supplementary material accompanies this paper.

Figure S1. Preparation of SCP.

This material is available as part of the online article from http://www.scielo.br/cta 